\title{
WHAT HAPPENS DURING THOSE LONG HOURS NEXT TO THE ROAD? AN EXPLORATORY STUDY OF THREE INFORMAL DAY LABOUR HIRING SITES IN TSHWANE
}

\section{Rinie Schenck, Lawrence Xipu, Derick Blaauw}

\section{INTRODUCTION}

Valenzuela (2002) calls people who congregate at informal pick-up points to seek for work for the day, by the hour or for a specific job, day labourers and the pick-up points hiring sites. These hiring sites are described as open-air geographical locations, such as street corners, pavements, car parking lots and factory gates (Blaauw, 2010), where day labourers seek employment (Valenzuela, 2003). Day labourers and the hiring sites appear to be a growing feature in South Africa and in many parts of the world. For example, in Japan in 1998 the number of day labourers who gathered at hiring sites was estimated to be as high as 1.26 million and in the USA the number of day labourers doubled from 1995, being estimated at 117000 in 2004 (Gill, 2001:2; Grow, 2003:5; Louw, 2007:99).

In line with the international trend, South Africa has in the region of 45000 of day labourers who assemble at around a 1000 hiring sites (Blaauw, 2010). These sites are a source of concern to residents and shop owners with regard to issues such as unemployment, poverty, crime and environmental degradation ( $\mathrm{Nel}, 2008)$.

The rationale for this study was the researchers' need to know more about the dynamics of the hiring sites in Tshwane. This includes the geographical locations, physical features, the approximate number of people occupying the sites, and the activities and movements taking place during the course of the day.

\section{THE AIM OF THE ARTICLE}

The aim of the article is to describe and analyse the socio-economic and relational social activities at three open-space hiring sites in Tshwane. This study is therefore exploratory and descriptive in nature. It will indicate the movements of the day labourers, who picks them up, how many day labourers are picked up by employers, and how they spend those long hours next to the road.

\section{RESEARCH METHODOLOGY}

The research approach used in this exploratory study was descriptive and the methodology was qualitative. Exploratory research is defined as research conducted to study a topic that is relatively unknown. According to Neuman (1997:20), the purpose this type of research is to enable researchers to familiarise themselves with the basic facts relating to the topic of the study, to formulate a clear understanding of it, and to determine the necessity of undertaking further research on the topic.

The qualitative method was used on three selected informal hiring sites. Qualitative research is a method in which data are expressed in the form of words (Neuman, 1997:7). Descriptive research is a type of research which strives to provide a detailed description of the characteristics of a phenomenon. Neuman (1997:20) notes that the goals of this type of research are to accurately describe a process, mechanism or relationship between the aspects of the research topic, to provide a quantitative or thematic representation of the object of the study, and to clearly describe research data in a manner that can trigger possible new explanations. 
The interviews with the day labour workers were conducted by the second author, as he is able to speak a variety of African languages. He interviewed the men with an unstructured questionnaire. He furthermore observed and documented the daily activities at the three sites for a period of six months during 2007.

The observations were focused on the environmental features of the sites such as the infrastructure, which included the streets, pavements, grass, trees and chunks of stones and bricks that the day labourers utilised. Observations also focused on the activities that took place during the course of the day between the day labourers and the other people who were affected by the sites, such as potential employers, residents, commuters and businesses situated next to the sites.

Unstructured informal interviews are defined as a process in which the researcher involves the participants in dialogue and an exchange of views on issues that are relevant to the topic of the study with the aim of gaining an understanding of the participants' subjective perceptions (Erlandson, Harris, Skipper \& Allen, 1993:47; Neuman, 1997:16). In this study the researcher interacted with approximately 105 day labourers. This sample was drawn using proportional sampling, with the size of the hiring site in question as the guiding principle as far as possible. Given the fluid nature of the activities on the hiring sites, this approach was supplemented by convenience sampling to accommodate all occasions where the fieldworker could gain access to the day labourers. The interaction with the respondents focused on the description of daily activities at the sites, including processes of socialisation, mutual support and finding work.

\section{ETHICAL CONSIDERATIONS}

Ethical considerations were upheld by the researcher to ensure that the participants' ethical rights were protected; for example, the identities of the participants were protected and their names have not been disclosed, and no false promises were made to the participants about how they would benefit from the findings of the study. It was explained to the participants that their participation was voluntary and that they were free to leave the process at any stage and it was ensured that no harm (such as exposure to police or metro police harassment and psychological trauma) would come to the participants as a result of participating in the study.

\section{THEORETICAL ORIENTATION OF THE STUDY}

The theoretical approach used in the study was critical theory (Babbie, Mouton, Vorster \& Prozesky, 1998; Freire, 1970; Hope \& Timmel, 1995). Critical theory is described as a philosophical paradigm which emphasises that the study of social science should be accompanied by attempts to achieve transformation and emancipation to improve the conditions of marginalised groups in society (Babbie et al., 1998).

Critical theory was found to be appropriate for the study of informal hiring sites as it challenges us to critically examine the social processes that impact on the lives of people and the environment; furthermore, the recommendations flowing from this research will be provided to relevant stakeholders, for example, non-governmental organisations (NGOs) and local government structures, who can use the information to improve the day labour workers' circumstances.

\section{LITERATURE REVIEW ON DAY LABOUR HIRING SITES}

Although informal hiring sites are a recent phenomenon in South Africa, they have been in existence for many centuries in countries overseas. The study conducted by Harmse, Blaauw 
and Schenck, (2009:7) indicated that in 2005/2006 there were around 45000 day labourers in South Africa waiting to be picked up at around 1000 hiring sites.

\section{Classification of hiring sites}

According to Valenzuela (2003:326), hiring sites in the USA can be classified as connected or unconnected, and regulated or unregulated.

The term "connected sites" refers to those sites which are situated next to certain companies or businesses and attract day labourers who possess skills that are relevant to those companies. For example, a site situated next to a paint supply store or next to a gardening services company is a connected site. Day labourers at these sites also advertise those tools of the trade, for instance, paintbrushes and rollers, which are relevant to the businesses' products and services.

Unconnected sites are not connected to any specific company and attract day labourers who possess a wide variety of skills. These sites are usually situated along busy main roads where day labourers are conspicuous to prospective employers. For example, a hiring site where day labourers display tools for various vocations such as building, carpentry, gardening and tiling can be regarded as an unconnected site. The labourers stand at these sites for a number of reasons, such as being next to a garage/petrol station where they can get water, or a shop where they can get food, or a busy intersection where they are more visible to potential employers.

Regulated sites are those sites that have been formally established and are managed by various organisations. These sites are prevalent in the USA and are facilitated either by the state, NGOs or temporary agencies (Meyer, 2003:7; Peck \& Theodore, 2001:472). Blaauw (2010) found no evidence of such sites in South Africa.

Unregulated sites refer to those sites that have developed informally and which are not managed by any specific organisation. These sites appear to be prevalent in South Africa and one of the reasons this study was conducted was to obtain information about such sites.

All the sites selected were unregulated, two were connected, while one was unconnected. The last site, $\mathrm{C}$, originally appeared to be connected, but this turned out not to be the case.

\section{Informal hiring sites}

Informal hiring sites are usually situated in open-air places such as street corners, pavements, car parking areas and factory gates. Standing at these conspicuous places has been found to be to be an effective job-search strategy for thousands of unemployed poor people (Valenzuela, Theodore, Meléndez \& Gonzales, 2006:1).

Primarily attracted to informal hiring sites in the hope of finding any type of work, day labourers tend to assemble from the early hours of the morning and sell their labour to potential employers who pass by (Meyer, 2003:6). Through this strategy day labourers have managed to obtain temporary employment for a variety of jobs such as handing out pamphlets, loading and off-loading trucks, garbage removal, shelf packing, construction work, painting and gardening (The Economist, 2003:31).

Abram (2003:15) notes that informal hiring sites can be described as a jungle; in order to survive day labourers need to be brave, fast and tough. With their insecure socio-economic status, they are usually at risk of extreme poverty, abuse, harm and even death. They are vulnerable as they have to stand at a site in anticipation of getting a piece job and take whatever job they are offered no matter how dangerous, with no certainty that they will be fairly 
compensated for it. According to Osterman (2003:4), and The Economist (2003:29), employers tend to pay less than they promise and are likely to engage day labourers in jobs that are hazardous.

Gonzo and Plattner (2003:45-46) conducted research on the informal hiring sites on the streets of Windhoek in Namibia and interviewed 160 day labourers. Their findings indicate that being unemployed and searching for work by standing on the streets is a harsh experience as day labourers tend to feel depressed and experience a sense of loss of control, helplessness and low self-esteem. These findings are consistent with those of Schenck and Louw (2005:93), who studied day labourers at Elardus Park in Tshwane and found that waiting for long hours at an open-air site is a difficult experience for day labourers exposed to harsh climatic conditions.

\section{Formal hiring sites}

Formal hiring sites are sites that are formally regulated by various organisations such as statefunded NGOs, church institutions and agencies which place workers on a temporary basis ("temp" agencies). The first formal site was probably established in the 1980s in California and there are currently about 100 formal sites in the USA. These numbers are reported to be increasing at a significant rate in the cities (Meyer, 2003:7). These sites are called by various names such as hiring halls (Peck \& Theodore, 2001:472), day labour plazas (Meyer, 2003:4), work centres (The Economist, 2003:30) and day labour shelters (Rivera \& Wiseman, 2003:1).

The purpose of establishing formal hiring sites is to improve the socio-economic situation of day labourers (Valenzuela et al., 2006:23), minimise exploitation and provide protection through labour laws. The sites also strive to protect the rights of other relevant stakeholders such as prospective employers, business owners and residents. They are often established in areas that are accessible to day labourers and prospective employers, and that are not too close to residential areas. In addition, they strive to promote socially appropriate behaviour by not allowing alcohol abuse, illegal drugs or dangerous weapons (Rivera \& Wiseman, 2003:13).

Abram (2003:8) notes that one of the most successful formal hiring sites is situated in Glendale, California. It is a project that is jointly coordinated by the Roman Catholic Church, the local government and the police department. The site is regulated by various policies to ensure that it is conducive to effective day labour work. It has an infrastructure facility which consists of picnic tables, garbage containers and public toilets. Day labourers are required to contribute a monthly fee of $\$ 25$ per month towards the maintenance of the site. Billboards are erected in the town to encourage prospective employers to employ day labourers at the site.

Another formal site that operates efficiently is called Macehualli Work Centre in Arizona (The Economist, 2003:29). Day labourers appear to prefer to use the site instead of standing on street pavements, where summer temperatures sometimes rise to 40 degrees Celsius. The site is managed by an NGO, which depends on charity donations for operational expenses. Day labourers are helped to get piece jobs, and this ensures that they are paid reasonable rates, averaging \$8 per hour (in 2003). Arrangements are made for them to be returned to the site after the completion of the piece job. About 150 day labourers occupy the site on a daily basis and begin to gather as early as $05 \mathrm{~h} 00$.

According to Peck and Theodore (2001:471), a number of agencies have established formal hiring sites in Chicago. These sites have names like Labour World, Ready Men, Temps Unlimited, World of Temps, Good Workers, Minute Men, Flash Employment, Labourama and Labour Power. "Temp" agencies tend to function more as business units than as charity organisations. They charge a fee for their placement services and in the process of mediating 
between day labourers and prospective employers, they strive to maximise their profit. For example, Labour Ready, a temporary agency based in Tacoma, Washington, placed about 600000 day labourers in 2002, earning $\$ 863$ million in revenue in the process.

\section{RESEARCH RESULTS}

From the 80 sites that were identified in Tshwane, three sites were selected for this in-depth study using a purposive sampling approach. It was planned to choose sites that represent connected and unconnected sites, and that were situated in a variety of socio-economic areas and in residential and business areas.

Site $\mathrm{A}$ is situated in an upmarket residential area (the affluent site), Site B is in the middle of the Tshwane central business district, where there are shops and businesses (the "military"/activist site), and Site C is a middle-income residential area (the "apathetic" site). The names of the sites were given by the fieldworker or second author. Below is an in-depth discussion of the themes that emerged from each site.

\section{Entry into the sites}

At all three sites the day labourers initially viewed the researcher with great scepticism. At Site A it was suggested he was someone from the local government who had come to chase them away. At Site B they challenged him to state on whose side he was on, the day labourers' or the business owners' in the area. The day labourers at Site C initially saw the researcher as a potential employer and immediately asked if he could provide them with piece jobs. Most of them drifted away when he explained that he was doing research. It appears that their initial negative attitude was influenced by their desperation to get piece jobs in order to relieve their immediate needs for income generation and material survival. Only after regular visits to the sites did the day labourers start to open up to the interviewer.

\section{Summary of the profile of the day labourers at the three sites}

TABLE 1

PROFILE OF THE DAY LABOURERS WHO GATHER AT THE SITES

\begin{tabular}{|l|l|l|l|}
\hline Feature & \multicolumn{1}{|c|}{$\begin{array}{c}\text { Site A } \\
\text { (affluent site) }\end{array}$} & $\begin{array}{c}\text { Site B } \\
\text { (military site) }\end{array}$ & $\begin{array}{c}\text { Site C } \\
\text { (apathetic } \\
\text { site) }\end{array}$ \\
\hline Average number of day labourers daily & 80 & 200 & 29 \\
Race & Black African & Black African & Black African \\
Gender & Male & Male & Male \\
Ages & $20-55$ & $18-60$ & $16-45$ \\
Cultural groups & Local and & Local and & Local and \\
& foreigners \\
freliminary estimates of daily nominal & R120-150 & R20-100 & R30-50 \\
income according to the day labourers & & & \\
\hline
\end{tabular}

Source: Survey data/observations by fieldworker

The distinct feature of the sites is the variance in the income earned at each site as indicated by the day labourers ${ }^{1}$. The range in income at the more affluent site is smaller, but it is higher than at either of the other sites. Site $\mathrm{C}$ is situated in a less affluent area and therefore people earn

1 The income estimates were obtained as part of the qualitative interviews.. 
much less. This is also the site where the foreigners and men from the northern, poor rural provinces (Limpopo) and countries (e.g. Zimbabwe) "enter" Tshwane. One of the men at Site C expressed the following:

"Life is tough when you don't have a permanent job and when your family is far away.

Sometimes we stay for two days without food."

The fieldworker observed that what was unique about Site $C$ was that the day labourers appeared to be hungrier and more desperate. A sense of extreme poverty and gloom appears to overshadow the site. Instead of pointing a finger upwards and making gestures to attract potential employers, the day labourers just stare at potential employers with "grimaces and eyes filled with anticipation" (fieldworker).

\section{The physical features of the sites}

As all three sites are informal hiring sites, they are situated on street corners and pavements. They lack infrastructure facilities such toilets, water, chairs, shelter and relevant services. Day labourers usually sit on the pavement on rocks and bricks. All the sites are in open-air areas. Sites A and B are situated next to large hardware stores, while Site C is situated next to a supermarket, shopping centre and a nursery. The shops are the reason for the day labourers being there, as they draw possible employers for construction or garden work and house maintenance. At Sites A and B the day labourers display their tool and skills explicitly for marketing purposes.

The day labourers indicated that they approach the shops to use their public toilets, but are usually denied access. When it rains they usually look for shelter close by, for example, at the garage/petrol station, but this causes friction between shop owners, customers and the day labourers (also compare Nel, 2008).

\section{Groups}

The day labour workers tend to separate themselves according to certain characteristics such as home language, age group and friendships. These groups tend to serve as a support system with regard to accessing piece jobs, food and accommodation. The groups also compete against each other to occupy a particular spot and attract the attention of prospective employers.

At Site B, according to a security guard, the older day labourers appear to gather together, to be more cooperative and reliable, and to come to the site daily. This is in contrast to the younger ones, who are rebellious and tend to stand defiantly in "forbidden" areas. The younger ones also tend to move around to different sites.

The immigrants try to be less conspicuous as they fear police raids, but can be distinguished by their darker complexion and unfamiliar accents. When selling their labour they tend to point a finger upward and say "Pick me makhosi". They are usually blamed for accepting extremely low wages and for allegedly taking job opportunities away from South Africans.

\section{Tension between local and foreign day labour workers}

At all the sites there was tension and suspicion between the local and foreign day labour workers. This revolved mostly around wages. In the words of one of the day labourers: "These Makwerekweres are spoiling the employers by charging R20.00 per day when we charge R100.00. They must go back to Zimbabwe and leave us alone”. This perception among local day labourers was later contradicted by Blaauw (2010). In his study Blaauw (2010:192) found that foreign day labourers in fact earn significantly more than South African-born day labourers in good times. In bad times the two groups earn more or less the same. This is most probably a 
reflection of the better educational levels and resultant higher productivity levels of foreign day labourers. There are examples in Mpumalanga where farmers actually pay their foreign labourers efficiency wages in order to retain their services. This is in stark contrast to existing perceptions and statements by politicians that foreign workers are being exploited by employers. Politicians suggest continuously that employers are undercutting the wages of South African workers in the process. The observed difference in earnings was achieved without any form of regulation or union activity (Blaauw, 2010:192).

Site $\mathrm{C}$ in particular appears to be an entry point for legal/illegal immigrants and day labour work was perceived to be the best way to enter the job market:

"Day labour work is the most feasible way of generating income. You don't need an ID document or certificates to get a job. In order to survive, you need to keep a low profile, to stay away from the police, to get a girlfriend who is a stay-in domestic worker for accommodation, and to impress your employer the day you get a chance to do a piece job. I don't want to go back to Zimbabwe because there is poverty there. At least here I can work, save money and send it to my family in Zimbabwe."

This finding is analogous to the findings of Valenzuela et al. (2006) that day labouring is an important point of entry for immigrants from Latin America into the United States labour market.

\section{Advertising skills}

At Sites A and B the day labourers appear to be entrepreneurial and ambitious. They bring their own tools and energetically display them to prospective employers. The skills that are advertised include bricklaying, paving, plastering, carpentry and painting. They also carry plastic bags which usually contain overalls, lunch boxes and water bottles. They displayed a strong sense of ownership of the sites and indicated that they do not wish to relocate to other sites as the work opportunities were sufficient. The situation at Site C (apathetic site) is completely different. The day labourers here did not bring or display any tools. It seems they still had to learn the "tricks of the trade".

\section{Relationship with employers, shop owners and residents}

The management of the businesses are unhappy about the presence of the day labour workers as they complain that it tends to worry customers, who are concerned about car thefts and other forms of crime. The day labourers, on the other hand, claim that they have reduced crime as they do not allow trouble makers to stand at the site. At Site B the high level of conflict between the day labourers, commuters and shop owners was noticeable - hence the label "military" site. There are shops that are sympathetic to day labourers and allow them to store their belongings on their premises. Across the street is the hardware store which represents good prospects for finding piece jobs as customers need skilled people to do menial jobs. The shop employed security guards, however, to chase day labourers from their premises and force them to stand across the street. The day labourers also mention negative experiences:

"Some motorists driving through the site are hostile and reckless. Some day labourers have been hit by fast speeding cars and when they reported the matter to the police nothing was done to arrest the perpetrators."

"Some corrupt police officials solicit bribes from day labourers who are illegal immigrants, thus plunging the day labourers further into poverty and desperation." 
At the same time there are also those residents who treat them well and provide food and support. None of these activities such as the provision of food were observed by the fieldworker.

\section{Negotiation with employers}

When a prospective employer stops at the site, the day labourers usually rush and surround the car. Some try to open the vehicle doors and others jump on the back of the van. Competition is rife as each day labourer tries to gain the attention of the employer. The negotiation between the employer and employee is usually done in a hurried manner and the researcher noted that day labourers tend to accept any offer or menial job they are given without any complaints. The employer, usually sitting inside his vehicle, has to choose a labourer from a group that has surrounded him. There is usually no time to do job interviews and to verify the credentials and competencies of the potential employee. Thus the employment process is as much a risk for the employee as it is for the employer and sometimes results in disappointments, unfulfilled promises and exploitation. Valenzuela et al. (2006:14) mention that as a result of the unregulated nature of the employment process, there have been reported incidents of exploitation and wage theft, which indicates that informal hiring sites are to a certain extent not conducive to proper ethical employment practices. The workers usually say that they can do "any job". Afterwards these hurried negotiations can create problems as indicated by the following scenarios:

"Some employers allegedly failed to pay a day labourers at the end of the day, saying that they will be picked up the following day and paid the whole amount when the job is finished. These employers never kept their promises, thus robbing a day labourer of his pay."

"Another day labourer was paid R40.00 when he expected at least to be paid R80.00 as he felt that he had worked very hard that day. The employer did not negotiate the pay with him when he picked him up as the day labourer had to quickly jump inside the van to be ahead of other competing day labourers."

Some of the day labourers have their own easier way of accessing work opportunities:

"Some prospective employers would arrive at the site during the day and inform specific labourers that they are going to negotiate contracts, and that should they get the business, they will come and hire them for the day. Thus, when potential employers arrive at the site, they do not pick any day labourer haphazardly, but look for specific workers who have worked satisfactorily for them in the past."

"Some of the labourers are very lucky as employers know them and they get piece jobs almost every day. If these labourers are your friends, then they can recommend you when there is extra work to be done. It is important to prove yourself to the employer that you are a good worker so that he will hire you the next time around."

The results of the study conducted by Blaauw and Pretorius (2005) confirm the notion that the building of a longer-term relationship with a particular employer is reflected in higher earnings in good times:

"When you befriend an edge trimmer and buy him "itakana" (liquor) regularly, you are sure to become one of the regulars in the gardening service."

"White employers in this area (Site A) mostly speak Afrikaans and they like workers who know Afrikaans because they know that you will be able to understand instruction and do what they want." 
This experience is also confirmed by empirical results. A study of Tshwane day labourers in 2004 by Louw (2007) showed that day labourers who are able to speak English and Afrikaans well earned higher levels of income. At the time those who declared that they did not understand Afrikaans received an average of R630 per month, while those who said that they speak Afrikaans well received R682.96 per month on average (Blaauw \& Pretorius, 2005).

The need for formal regulated hiring sites was expressed by the day labourers.

\section{Arrival and departure from the sites}

Day labourers usually arrive at about $06 \mathrm{~h} 00$ in the morning at the sites. Those that have been lucky to get prearranged jobs are picked up by employers and transported to the work sites and usually depart from there to their homes after the work has been done. Those that do not have piece jobs hang around at the sites and usually leave at about $14 \mathrm{~h} 00$ in the afternoon. This observation is consistent with the research findings of Gonzo and Plattner (2003:59) and Valenzuela et al. (2006:4), who noted that there appears to be a general pattern with regard to the arrival and departure of day labourers at the sites. This observation indicates that the movement of day labourers to and from the sites follows a more-or-less fixed routine and that chances of getting a piece job are much better in the early morning than in the afternoon, hence they are present in the mornings and depart from the sites in the afternoons.

During the early morning hours (06h00-07h30) the site functions more like a pick-up point as day labourers are picked up by employers based on specific prearrangements. The researcher noted that on average approximately 20 day labourers are picked up daily at Site A. The average for Site B is 50 day labourers and at Site C an average of approximately 10 day labourers were picked up daily.

The times between $07 \mathrm{~h} 30$ and $09 \mathrm{~h} 00$ are marked by an increase in the number of day labourers at the site and it is during this period that the number reaches its peak. This is also the period when activities aimed at canvassing for work are most pronounced. Day labourers would often put on their overalls and energetically point a finger upwards and display their tools to cars passing by as well as to customers at the nearby hardware store and petrol station.

\section{Waiting/socialising period}

If the day labourer does not manage to get a job by around $10 \mathrm{~h} 00$, the mood changes from looking for work to socialising. It is as if the day labourers have accepted that they were not lucky in securing a job for the day, and they start animated conversations about women, alcohol and crime seemingly to distract themselves from the harsh realities of poverty and unemployment. They divide into small groups and share their food and water, or start playing games like "morabaraba" and poker. Others isolate themselves and sit a distance away from the group. These lone day labourers informed the researcher that sitting alone gives them time to think about their situation. They also said that sometimes it is advantageous to sit alone as prospective employers tend to avoid groups and focus on single day labourers. However, in spite of socialisation, day labourers still keep a vigilant eye on cars passing by or customers at the hardware store in case there is someone wanting menial work to be done at his house.

To some day labourers piece jobs are not "real" jobs, but just a strategy to access "pocket" money. They therefore use the money they earn on entertainment:

"When I earn "a draad" [R100.00], I like to spend it by going to a tavern with my friends where there is Kwaito music, to have cold beers with "isifebe" (a sexy woman) sitting next to me." 
Alcohol abuse appears to be one of the problems at Site B as some of the day labourers tend to engage in excessive drinking. Once they get paid, they do not come to the site the following day even when prearrangements have been made to pick them up. They come back when their money is finished. One employer informed the researcher that if you want to get these skilled workers who have drinking problems, you must get to the site as early as possible, because after 10h00, they start drinking and show no interest getting a piece job.

\section{Impact of seasonal changes}

The researcher noted that seasonal factors have an impact on the movement of day labourers at the sites. Inclement weather such as extreme heat, cold, rain and wind tends to reduce the number of day labourers standing at the sites. This can be attributed to the fact that day labourers are exposed to harsh weather as the sites are roofless. Valenzuela et al. (2006:4) concur and state that the number of day labourers standing at the sites differs according to seasonal changes. This indicates that the conditions at the hiring sites are uncomfortable because of the lack of appropriate infrastructure, which means that day labourers are vulnerable and have no protection against inclement weather.

\section{CONCLUSIONS AND RECOMMENDATIONS}

Day labourers are a group on the margins of service delivery by social service professionals. The following issues can be addressed regarding day labourers who stand on the street corners of our cities and towns for the benefit of the day labourer as well as those affected by their presence.

\section{The establishment of a day labourers' forum}

Support groups among day labourers could be organised. Such meetings could provide a forum for mutual support and engagement with relevant stakeholders. It is crucial for policy makers at government level and other stakeholders to acknowledge that in order to reach a lasting solution to the problem, people who are directly affected should be consulted and their input should be incorporated into any identified solution(s).

\section{The formulation of formal hiring sites}

Informal hiring sites lack infrastructure such as shade, toilets and water; they are exposed to harsh weather and exploited by some employers. It would be desirable to negotiate the establishment of formal hiring sites with local government with the participation of various stakeholders. Formal hiring sites have been successfully established in the USA and it has been proven that they have significantly improved the socio-economic circumstances of day labourers.

\section{Skills development programmes}

The hiring sites are occupied by workers who are utilised to perform menial jobs as they are unskilled and semi-skilled. This indicates that there is a need for skills development to make day labourers more marketable and to enhance their income-generation potential. The content of the programmes could be determined by the day labourers' needs as well as the type of skills needed in the market place.

\section{Job search assistance strategies}

The current job search strategies of day labourers include pointing a finger upwards and displaying tools. These can be built upon and other creative options such as displaying bill boards and posters, and producing certificates and reference letters can be considered. In addition, if formal hiring sites can be established, the management of the sites can play a mediating role in employer-employee negotiations to ensure that day labourers are given jobs 
regularly and are paid what they deserve. The literature review has shown that the formal hiring sites established in the USA have played a significant role in assisting day labourers to find regular work and to ensure that they are paid a decent wage.

\section{Access to comprehensive social services}

Informal hiring sites are clearly a poverty pocket in our society as day labourers are poor and destitute. A comprehensive service delivery programme could be formulated and implemented at the sites to ensure that day labourers have access to appropriate social services.

As long as there are those who spend their hours on the street corners in South Africa in search of an income-earning opportunity rather than venturing into more lucrative criminal activities, society owes it to this informal labour market to continue research efforts in this area in order to find sustainable solutions for this socio-economic phenomenon.

\section{REFERENCES}

ABRAM, S. 2003. Hiring Centre for day labourers in Glendale Calif., struggles in soft economy. Daily News. 28 July. [Online] Available: http://web22.epnet.com/Delivery PrintSave.asp?tb=1\&. [Accessed: 19/02/2004].

BABBIE, E., MOUTON, J., VORSTER, P. \& PROZESKY, B. 1998. The practice of social research. (South African edition). New York: Oxford University Press.

BLAAUW, D., LOUW, H. \& SCHENCK, R. 2006. The employment history of day labourers in South Africa and the income they earn - a case study of day labourers in Pretoria. South African Journal of Economic \& Management Sciences, 9(4):458-471.

BLAAUW, P.F. 2010. The socio-economic aspects of day labouring in South Africa. Johannesburg: Department of Economics \& Econometrics, University of Johannesburg. (Unpublished DCom Thesis)

BLAAUW, P.F. \& PRETORIUS, A.M. 2005. Day labourers in Pretoria: entrepreneurial spirit in action or survivors in a cul de sac? Paper presented at the Annual Conference of the Southern Africa Institute for Management Scientists, Bloemfontein, University of the Free State, 26-28 September 2005.

ERLANDSON, D.A., HARRIS, E.L., SKIPPER, B.L. \& ALLEN, S.D. 1993. Doing naturalistic inquiry: a guide to methods. New Delhi: Sage Publications.

FREIRE, P. 1970. Pedagogy of the oppressed. New York: Continuum.

GILL, T. 2001. Men of uncertainty: the social organisation of day labourers in contemporary Japan. Albany: State University of New York Press. [Online] Available: http://web22.epnet.com/DeliveryPrintSave.asp?tb=1\&. [Accessed: 19/02/2004].

GONZO, W. \& PLATTNER, I.E. 2003. Unemployment in an African country: a psychological perspective. Namibia: University of Namibia Press.

GROW, B. 2003. A day's pay for a day's work - maybe. Business Week, 12 August. [Online] Available: http://web22.epnet.com/DeliveryPrintSave.asp?tb=1\&. [Accessed: 19/02/2004].

HARMSE, A., BLAAUW, P.F. \& SCHENCK, R. 2009. Day labourers, unemployment and socio-economic development in South Africa. Urban Forum, 20(4):363-377.

HOPE, A. \& TIMMEL, S. 1995. Training for transformation. Zimbabwe: Mambo Press. 
LOUW, H. 2007. Men at the margins: day labourers at informal hiring sites in Tshwane. Pretoria: Department of Social Work, University of South Africa. (Unpublished PhD Thesis)

MEYER, P. 2003. Dallas Morning News, 18 October. [Online] Available: http://web22.epnet.com/DeliveryPrintSave.asp?tb=1\&. [Accessed: 19/02/2004].

NEL, D. 2008. An exploratory study of the perceptions of people affecting and affected by day labourers at hiring sites in Tshwane. Pretoria: Department of Social Work, University of South Africa. (Unpublished MA Dissertation)

NEUMAN, W.L. 1997. Social research methods: quantitative and qualitative approaches $\left(3^{\text {rd }}\right.$ ed). Boston: Allyn \& Bacon.

OSTERMAN, R. 2003. Bill would protect day labourers. Chicago Tribune, 24 July. [Online] Available: http://web22.epnet.com/DeliveryPrintSave.asp?tb=1\&. [Accessed: 19/02/2004].

PECK, J. \& THEODORE, N. 2001. Contingent Chicago: restructuring the spaces of temporary labour. International Journal of Urban and Regional Research, 25(3):471-496.

RIVERA, E. \& WISEMAN, M. 2003. WETA accepts decision on day labourers' shelter. The Washington Post, 2 August. [Online] Available: http://web22.epnet.com/Delivery PrintSave. asp?tb=1\&. [Accessed: 19/02/2004].

SCHENCK, R. \& LOUW, H. 2005. An exploratory study on day labourers in Pretoria. Social Work/Maatskaplike Werk, 41(1):84-95.

THE ECONOMIST. 26 July 2003. An answer or a problem? [Online] Available: http://web22.epnet.com/DeliveryPrintSave.asp?tb=1\&. [Accessed: 19/02/2004].

VALENZUELA, A. Jr. 2002. Working on the margins: immigrants in day labourers work. Migraciones Internacionales, 1(2):5-28.

VALENZUELA, A. Jr. 2003. Day labourer work. Annual Review of Sociology, 29(2):307-333.

VALENZUELA, A. Jr, THEODORE, N., MELÉNDEZ, E. \& GONZALES, A.L. 2006. On the corner: day labor in the United States.: Unpublished report. Centre for the Study of Urban Poverty, UCLA. Los Angeles.

A previous version of this paper was presented at the $22^{\text {nd }}$ Annual Conference of the Southern Africa Institute for Management Scientists (SAIMS), Mpekweni Beach Resort, 12-15 September 2010.

\section{Acknowledgement}

The authors acknowledge the financial contribution of the NRF to the research as well as the valuable comments of the anonymous referee(s).

Prof Rinie Schenck, Department of Social Work, University of the Western Cape; Mr Lawrence Xipu, Department of Social Work, Unisa; Associate Professor Derick Blaauw, Department of Economics and Econometrics, University of Johannesburg, Johannesburg, South Africa. 